\title{
LECTURE
}

\section{WOMEN AND ANTIWAR PROTEST: REARTICULATING GENDER AND CITIZENSHIP}

\author{
KATHRYN ABRAMS
}

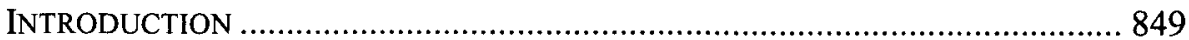

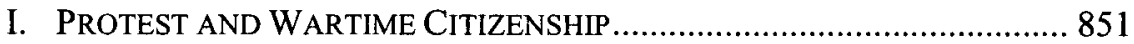

A. The Ambivalent Status of Protest.............................................. 851

B. Wartime Citizenship ............................................................. 852

C. The Contemporary Context of Women's Antiwar Protest ........... 856

II. THREE WOMEN'S ANTIWAR MOVEMENTS ......................................... 858

A. Cindy Sheehan and the Camp Casey Vigil ................................. 858

B. CODEPINK for Peace ......................................................... 863

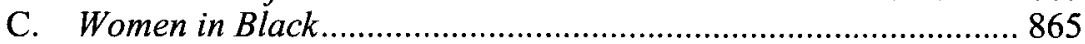

III. REARTICULATING GENDER, RECREATING CITIZENSHIP ........................ 868

A. Gender and the Body Politic .................................................. 868

1. The Angry Mother........................................................... 869

2. The Gendered Direct-Action Performer ................................ 871

3. The Woman as Witness....................................................... 872

B. Gendered Antiwar Protest and Political Efficacy ...................... 872

C. Gendered Antiwar Protest and the Paradoxes of Women's

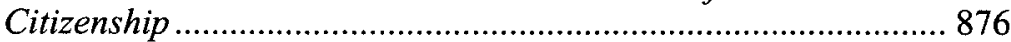

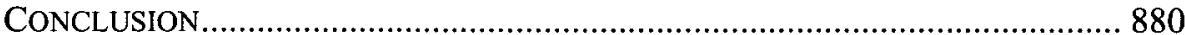

\section{INTRODUCTION}

Law, like many other disciplines, has seen a recent rekindling of interest in questions of citizenship. ' Debates about immigration, about the meaning and

* Herma Hill Kay Distinguished Professor of Law, UC-Berkeley School of Law (Boalt Hall). I presented an earlier version of this article as the Distinguished Lecture at Boston University School of Law in Spring 2007. I am grateful to the lively and challenging faculty comments I received at that lecture, as well as at the Dimensions of Women's Citizenship Conference at Hofstra University School of Law, at the Gender and Law Conference at Santa Clara Law School, and at faculty workshops at University of Oregon School of Law and DePaul University College of Law. Thanks also to K.T. Albiston, Helen Borrello, Amy Kapczynski, and Hila Keren for conversations on the subject of this article.

' See, e.g., Symposium, A Tribute to the Work of Kim Barry: The Construction of Citizenship in an Emigration Context, 81 N.Y.U. L. REV. 1 (2006) (reflecting on citizenship in an emigration context); Symposium, Eighth Annual LatCrit Conference City \& The 
obligations of American citizenship post-9/11, and about the domain of citizenship in a world shaped by both ethnic nationalism and the forces of globalization, have given this familiar topic new salience. Yet paradoxically, protest - a dimension of citizenship that these debates have inspired - has not been systematically revisited. In this paper, I consider protest as an activity of citizenship, by analyzing its practice in a particular context: the waging of war. ${ }^{2}$ I also analyze such protest, as it has been undertaken by women, acting as women. This focus holds intrinsic interest to me, as a feminist scholar. However, focusing on the activity of a specific group of citizens - particularly one which has historically sustained a vexed relationship to citizenship - is consistent with the emerging theoretical framing of citizenship as a status and activity which is both differentiated and differentiating. ${ }^{3}$

I begin, in Part I.A, by examining protest in the context of conventional understandings of political citizenship. I reflect on, in particular, which features of these understandings make it controversial for women to protest war and necessary for them to invoke traditional aspects of gender in so doing. In Part I.B, I consider the aspects of gender that have been mobilized as justifications for having a perspective on war-making. In Part I.C, I examine the present context of women's antiwar protest, in which women's shorterterm strategies in protesting unpopular wars must co-exist, sometimes uneasily, with their longer-term interest in securing legitimacy, as citizens capable of participating, and even leading, in the varied context of democratic selfgovernment. In Part II, I concentrate on three recent movements - Cindy Sheehan's Camp Casey vigil and related activism, CODEPINK for Peace, and Women in Black - and assess how protesters have reformulated these claims about gender, at a time when the stakes are simultaneously lower and higher than in previous periods, and neither feminists nor most other women subscribe to simple, unitary conceptions of motherhood or the relationship between women and peace. In Part III, I examine the resulting rearticulations of gender, and the often innovative modes of political action that have served to project these more complicated understandings, and ask how they serve the goals of women's antiwar protest, and women's acceptance as full and legitimate participants in public life. I conclude with some final reflections on

Citizen: Operations of Power, Strategies of Resistance, 52 ClEV. ST. L. REv. 1 (2005) (addressing a range of citizenship issues).

${ }^{2}$ As will be clear below, while my primary focus will be on protests related to the American war on Iraq, I will consider more briefly protest activity connected with the Israeli occupation of the Palestinian territories, the disappearance of civilians in Argentina, and inter-ethnic warfare in the former Yugoslavia.

3 See generally RUTH Lister, Citizenship: Feminist Perspectives (2d ed. 2003) (describing different forms or levels of citizenship and the ways in which citizenship can operate as an exclusionary mechanism both in regard to a particular state, and within the boundaries of that particular state); Linda Bosniak, Universal Citizenship and the Problem of Alienage, 94 Nw. U. L. REV. 963 (2000) (articulating different, sometimes hierarchized, dimensions of citizenship). 
what these efforts suggest about emergent possibilities for women's citizenship.

\section{PROTEST AND WARTIME CITIZENSHIP}

\section{A. The Ambivalent Status of Protest}

Protest fits somewhat ambivalently within the theoretical typologies of political citizenship, even though we think of it as an activity in which the citizens of democracies frequently engage. Although some typologies frame the meaning of citizenship by reference to rights, and other obligations, protest may be understood as falling on both sides of the divide. ${ }^{4}$ Within the American political system, protest may be protected by the First Amendment, placing it squarely within a liberal, rights-based understanding of citizenship. Yet understood in another way, critiquing what one views as unjust or misguided governmental policies would seem one of the obligations of an "active" form of citizenship. This active form of citizenship might draw on quasi-republican understandings - that citizenship extends beyond the formalities of voting or claiming rights - or Foucaultian notions of a diffused sphere of the political, ${ }^{5}$ comprehending the formal and the informal, and comprising not only official discourses but acts of resistance and rearticulation.

Historically, the realm of political critique and protest has also been gendered. Only men, and mostly men whose other characteristics established them as privileged, have been able to claim the authority and the comprehensiveness of vision to mount a systematic political critique. When women, who have historically been sequestered from the public realm, ${ }^{6}$ have entered the sphere of protest and political critique, they have had to rely on those gendered characteristics that constitute their more limited sources of authority. These characteristics include motherhood, the capacity for care and order that stems from domestic responsibility, and a particular kind of conformist moral virtue traditionally associated with these gendered roles. Although this discourse may have contributed to women's marginalization, women have employed it effectively to influence public debate. Particularly when mounting critiques of exclusion, ${ }^{7}$ or calling attention to failures of social

${ }^{4}$ See, e.g., LISTER, supra note 3, at 13-42 (examining the question "what is citizenship?" in light of typologies based on rights or obligations).

${ }^{5}$ See, e.g., Kirstie McClure, On the Subject of Rights: Pluralism, Plurality and Political Identity, in Dimensions of Radical Democracy: PluRalism, Citizenship, Community 108 (Chantal Mouffe ed., 1992).

${ }^{6}$ See LiSTER, supra note 3, at 68-73, $119-30$ (discussing women's historical exclusion from citizenship in political theory and arguing for greater access to the public sphere).

7 The mid-nineteenth-century campaign for women's suffrage in the United States reflected these claims of women's distinctive, domestically-derived political virtues. See Ellen Carol DuBois, Feminism and Suffrage: The Emergence of an IndePEndent WOMEN'S MOVEMENT IN AMERICA 1848-1869, at 37, 44-47 (1978) (discussing women's 
welfare provision, ${ }^{8}$ women making these traditional, gender-based claims have sometimes been successful in garnering attention or soliciting responses from mainstream political actors.

\section{B. Wartime Citizenship}

The meaning of citizenship is importantly transformed during wartime. During a time of armed conflict, when a state is fighting for its continued existence or for values central to its self-definition, the obligations of citizenship rise to the forefront, increasing in seriousness and magnitude. The rights of the citizen - understood as claims that the citizen can make against the state - are deemed either secondary or subject to atypical circumscription

The most important wartime obligation of citizenship is that of bearing arms on behalf of the state, and risking one's life in that effort. This may be a formal obligation in nations that have a draft. In nations such as the United States which do not have a draft, even in wartime, it may be a responsibility that is not obligatory but perceived as normative for citizenship. In virtually all countries, bearing arms on behalf of the state is a gendered obligation. Men are the paradigmatic citizens whose obligation extends to dying for their country, whereas women are almost never subject to mandatory military service. In nearly all contexts in which women serve, they carry out genderdifferentiated responsibilities, ${ }^{9}$ which position them outside or farther from the lines of combat. Women have in fact died in these ostensibly support-oriented roles, ${ }^{10}$ which gives them a claim in antiwar protest that is new, but not deployed in the movements on which I focus.

Women's historic - and to a large degree paradigmatic - obligation of citizenship during wartime is to support the war effort through the resolute and patriotic surrendering of their family members to military service. Women may also be asked to provide ancillary support for the war effort, whether this

rights activists' simultaneous belief in women's domestic nature and in women's entitlement to participate fully in public life).

${ }^{8}$ See Seth Koven \& Sonya Michel, Introduction: "Mother Worlds," in MOTHERS OF A New World: Maternalist Politics and the Origins of Welfare States 1-2 (Seth Koven \& Sonya Michel eds., 1993) ("During periods when state welfare structures and bureaucracies were still rudimentary and fluid, female reformers, individually and through organizations, exerted a powerful influence in defining the needs of mothers and children and designing institutions and programs to address them.").

${ }^{9}$ Even in Israel, where military service is mandatory for women as well as men, it has historically been subject to a wider range of exclusions, and it is distinct both in duration and in the responsibilities that one may be assigned. See Noya Rimalt, Women in the Sphere of Masculinity: The Double-Edged Sword of Women's Integration in the Military, 14 DUKE J. GENDER L. \& POL'Y 1097, 1113-15 (2007) (discussing the ongoing gender differentiation of the Israeli Defense Force).

${ }^{10}$ See, e.g., Sara Corbett, The Women's War, N.Y. TIMES, Mar. 18, 2007, § 6 (Magazine), at 42 ("Despite the fact that women are generally limited to combat-support roles in the [Iraq] war, they are arguably witnessing an historic amount of violence."). 
be employment in military industries, such as that undertaken by women in the United States during World War II, ${ }^{11}$ or more conflict-related tasks, such as fire-watching during the WWII bombings in Britain. ${ }^{12}$ As historian Sonya Rose has argued, drawing on the history of WWII, women are understood to bear other kinds of gendered citizenship obligations during wartime, such as maintenance of "moral virtue" in the realm of sexuality and the responsible guardianship of the home and hearth. ${ }^{13}$ As Rose points out, these were understood to be central responsibilities of citizenship during WWII, and significant governmental and popular energies were devoted to policing the fulfillment of these responsibilities ${ }^{14}$ - disciplining women even when their failures in these traditionally gendered responsibilities were attributable to their need to fulfill non-traditional roles of civic responsibilities - such as civil defense roles or fire-watching during the bombing of Britain. ${ }^{15}$ Because their most important wartime responsibilities are to family and sexual or familial moral rectitude, women's service to the state is indirect, and mediated by their familial roles. ${ }^{16}$

The act of protesting a particular war is a distinctively vexed activity of citizenship for citizens of any gender. Under a rights-based framework, it declares a right to criticize the government (or to resist the government's imposition of political obligations) at a time when one's obligations to the government, rather than one's rights against it, are deemed paramount. Alternatively, protest interprets one's civic obligation as consisting of engaged critique or resistance, rather than the reliable, disciplined, "patriotic" performance of prescribed responsibilities, at a time when the performance of such responsibilities is considered supreme. Because wartime dissent or protest is a perilous business for any citizen, most protesters feel compelled to

11 See, e.g., DORIS WEATHERFORD, AMERICAN WOMEN AND WORLD WAR II 128-39 (1990) (discussing women's wartime participation in various industries essential to the war effort); EMILY YELLIN, OUR MOTHERS' WAR: AMERICAN WOMEN AT HOME AND AT THE FRONT DURING WORLD WAR II, at 48-65 (2004) (discussing women's wartime participation in the aircraft, shipbuilding, and munitions industries).

12 See, e.g., James Hinton, Women, Social Leadership, ANd the Second World War: CONTINUITIES OF CLASS 77-81, 92-97 (2002) (describing various wartime roles that female volunteers in Britain undertook, including civil defense and keeping watch for potential air raids).

13 Sonya O. Rose, Sex, Citizenship, and the Nation in World War II Britain, 103 AM. HIST. REV. 1147, 1166-73 (1998) ("The World War II obsession with the morality of girls and young women in Britain was thus articulated in terms that constructed moral subjects as responsible citizens.").

${ }^{14}$ See id.

15 See Hinton, supra note 12 , at 77-81, 92-97.

16 This arrangement has some resonances with the common law concept of coverture, whereby a woman was assimilated into the legal personhood of her husband upon marriage. See LISTER, supra note 3, at 69 (discussing the historical significance of "coverture" in the Anglo-American legal tradition). 
invoke characteristics that give them legitimacy in the eyes of the government and the public. They may critique the ends or means of the war, by reference to some set of ostensibly shared political goals, such as avoiding an excessive or unnecessary cost of human lives. But since citizens often know less about the goals or tactics of the war than those in the government, making this kind of claim to legitimacy is usually successful only in those cases where the failings of the war effort have become transparent. Alternatively, one effective means of gaining legitimacy is for the speaker to make a claim of individual sacrifice in the war effort. The speaker's sacrifice demonstrates the performance of a burdensome civic obligation, but it also demonstrates that the speaker has gained sufficient knowledge regarding the war effort to speak with an authority comparable to that of the government. One of the most persuasive claims in wartime protest is the claim to ground one's critique of a particular war in experience or perspective derived through military service. Thus a group like Vietnam Vets Against the War acquired the requisite legitimacy to criticize that conflict. ${ }^{17}$

Access to this highly credible kind of claim is usually gendered, meaning that it is most frequently and effectively made by men. Women have never been drafted for military service in the United States, and when they have served it has not been in formal combat roles. ${ }^{18}$ Even when their ostensible combat support roles have placed them near the front lines, their experiences have rarely been a source of critique. ${ }^{19}$ This pattern is, in large part, a paradoxical effect of American women's particular path into the military: American women have fought so hard for the right to play even combat

17 According to Vietnam Veterans Against the War co-founder Jan Crumb:

[A]t a certain point they didn't want to debate us any longer, because we knew what we were talking about. Not only had we been there, but we'd taken the time and trouble to read the Geneva Accords, and the government officials were constantly lying about what these documents said. So we would quote from the documents, or even have copies of them to hand out. They couldn't stand that situation - that was how shaky the government's position really was.

Gerald Nicosia, Home to War: A History of the Vietnam Veterans' Movement 2324 (2001).

${ }^{18}$ Kenneth L. Karst, The Pursuit of Manhood and the Desegregation of the Armed Forces, 38 UCLA L. REv. 499, 523-45 (1991) (discussing and arguing against the exclusion of female military personnel from combat roles).

19 Women who have served in armed conflict are frequently more credible in claiming that they have been sexually harassed or assaulted by other service members in the course of their service. See, e.g., Helen Benedict, The Private War of Women Soldiers, Salon.com, Mar. 7, 2007, http://www.salon.com/news/feature/2007/03/07/women_in_military/index. $\mathrm{html}$ (interviewing women soldiers who have experienced sexual coercion from their fellow troops and have not felt adequately protected by the military). This may be an interesting reflection on the limited type of legitimacy that military service confers on women. 
support or quasi-combat roles that it would be not be surprising if those who occupy such roles were reluctant to confront the government over war. ${ }^{20}$

For women to critique war during wartime - to take part in this particularly vexed act of citizenship - they have generally needed to invoke their own gendered experience as a source of legitimacy or knowledge. This kind of appeal has historically taken one of two forms. First, women have invoked their roles as mothers of men who have been or could be conscripted to fight a particular war. ${ }^{21}$ Women have relied on their personal sacrifice - in facing the loss or injury of their sons - to make the costs of war more tangible to those more distant from the experience on the ground. In the second type of appeal, women claim that their role as mothers - actual or metaphorical, by virtue of their sex or gender - has given them an orientation toward care-giving and the preservation of life that provides a ground from which to expose the error of war. $^{22}$

Although these gendered claims may be the most effective means for women to conduct wartime protest, even they are not always successful in relation to the state, or uncontroversial among feminists and women in general. The claims of mothers that are based on their personal sacrifice in being asked to surrender their sons are vulnerable to official government strategies of cooptation or discipline. For example, historian Susan Zeiger ${ }^{23}$ has demonstrated the way in which the government countered an effort by mothers to protest the impending demand to surrender their sons in World War I through an official campaign to contrast patriotic (i.e., compliant) motherhood

20 Another interesting question is whether the public still views the experience one gains as a result of having performed military service in wartime in gendered terms. Would the average member of the public believe that even a woman who had served at the front in wartime has learned enough from the experience to frame a plausible critique? In other words, it is possible that, in the public mind, both masculinity and military experience are necessary in order to claim an informed perspective that is capable of authorizing an antiwar critique?

${ }^{21}$ See, e.g., Susan Zeiger, She Didn't Raise Her Boy To Be a Slacker: Motherhood, Conscription, and the Culture of the First World War, 22 FEMINIST STUD. 7, 10 (1996) ("For these female pacifists, it was motherhood that legitimated and motivated women's condemnation of war.... Motherhood in this abstract sense was a potent symbol which women pacifists invoked frequently and effectively. But real stories of the grief of real mothers were political tools of a more visceral sort.").

22 See id. (describing women's peace organizations shortly before World War I for which "pacifist maternalism - the idea that women have an innate affinity for peace due to their capacity for giving life - was the most distinctive and fully developed feature of [the women's peace movement's] ideology").

${ }^{23}$ Id. at 7-8 ("On the one hand, war culture valorized proper, 'patriotic' motherhood, defined by obedience to the state and the willing sacrifice of sons to the army; but it condemned 'unpatriotic' forms of mothering, which included feminist and pacifist activism and 'selfish,' overly emotional attachment to children."). 
with selfish, deviant (i.e., pacifist or resistant) motherhood. ${ }^{24}$ The "moral mother's" claim to resist war as a function of her innate or socialized preservationist instinct ${ }^{25}$ has been a more consistent and enduring one. Furthermore, it is consistent with the range of cultural-feminist claims that have legitimated women's involvement in active, participatory forms of citizenship. ${ }^{26}$ But such views have hardly been uncontested among feminists. As Micaela di Leonardo argued two decades ago, the "moral mother" image neglects the many, complicated ways that militarism uses, marginalizes, and attracts women; moreover, it venerates an image of women that has been, and can be, used to constrain and disadvantage them. ${ }^{27}$

This complexity raises a related point: the imagery and substance of women's antiwar protests inevitably operates in specific social and political contexts. Although women protesting their governments' war-making must face the paradigmatic complications of antiwar protest, they must also confront features of their particularized context that influence their strategies and shape the efficacy of their efforts. In the following section, I examine the determinative features of the present context of women's antiwar protest particularly in the United States following the 2003 invasion of Iraq.

\section{The Contemporary Context of Women's Antiwar Protest}

I would argue that three dimensions of the current social and political context have particular salience in shaping the antiwar efforts of women-led groups. First, in at least some of the contexts in which women have mobilized, the war efforts are either broadly unpopular, or seriously contested by groups apart from those led by women. Efforts such as the war in Iraq are neither widely supported, nor viewed by most Americans as placing the nation's survival or values in the balance. ${ }^{28}$ This has made the task of legitimizing

${ }^{24}$ The contemporary motion picture industry supported the government's narrative by creating films that communicated this theme. $I d$. at 8 .

${ }^{25}$ One of the most fully theorized and sophisticated accounts of this position may be found in Sara Ruddick, Maternal Thinking: Toward a Politics of peace 185-251 (1989) (detailing maternal thinking in regard to peace).

${ }^{26}$ One should note the use of similar maternalist claims to "clean up," or support high moral standards in government, in the last stages of the women's suffrage movement in the mid-nineteenth century. See, e.g., DuBols, supra note 7, at 173 (discussing feminist opposition to the Fifteenth Amendment on the ground that the exclusion of women from the franchise made "a man's government... worse than a white man's government with suffrage limited by property and educational qualifications").

27 See Micaela di Leonardo, Morals, Mothers, and Militarism: Antimilitarism and Feminist Theory, 11 FEMINIST STUD. 599, 615 (1985) (reviewing several books on women and militarism and arguing that feminists must "retire the Moral Mother from the field").

${ }^{28}$ Opinion polling data from September 2007 indicate that seventy percent of Americans disapprove of President Bush's handling of the war in Iraq, and that a majority believe that the United States should not have involved itself in that country. See PollingReport.com: 
one's dissent less urgent or onerous than, say, during the run-up to either of the World Wars.

Yet if gender or other justifications for antiwar protest are not as vitally implicated in processes of legitimation, they may nonetheless be deployed for other reasons. Those protesting the American occupation of Iraq or the Israeli occupation of Gaza or the West Bank face contexts in which the government has been resistant to, or at least slow to acknowledge, voices of dissent. Many protesters have sought to mobilize broad segments of the public in order ultimately to influence political leaders. Protesters' invocations of gender in such contexts have served not only as a ground of knowledge for objecting to war, or as a source of legitimacy, but as a basis for claiming public attention, in what is - in the United States, at least - a message-saturated political environment. Many groups, with many affiliations or identities, have protested the war; but the continuing salience of gender in American culture and politics, combined perhaps with women's historic association with pacifist efforts, has lent women-led antiwar efforts particular promise as attention-claiming vehicles.

Second, contemporary antiwar protests have taken place at a time when women are beginning to enter the political mainstream, and beginning to play an influential role in the processes of democratic self-government, from assuming positions of leadership (e.g., Supreme Court Justices, Secretary of State, Speaker of the House), to less visible but nonetheless politically-salient roles as legislators, policymakers, political consultants and participants in nongovernmental organizations. This breadth of participation is sufficiently new as to be unfamiliar, controversial, and potentially precarious - as the exciting yet uncertain campaign of the first front-running woman candidate for President suggests. In this environment - where women have entered, but have yet to achieve "critical mass" in most of these political contexts women's activities in any visible setting, including the volatile realm of political protest, may be taken as emblematic in ways that men's activities would not. They may therefore bear not only on the success of a larger antiwar movement, but on women's ability to win acceptance as legitimate political actors.

Finally, women are mobilizing these protests at a time when imagery related to gender is both more plural and more perilous. Women can draw on a wider repertoire of images and narratives to describe their "gendered lives," 29 but at the same time, both participants and the public recognize that generalizations about women (particularly those that draw on nineteenth-century separate spheres ideology) can be a dangerously double-edged sword.

\footnotetext{
Iraq, http://www.pollingreport.com/iraq.htm (last visited Sept. 22, 2007) (providing the results of a CBS News Poll for September 14-16 of 706 adults nationwide).

29 The plural yet broadly-evocative notion of "gendered lives" comes from MARTHA albertson fineman, The Neutered Mother, the Sexual family and Other Twentieth Century TRagedies (1995).
} 
In the next section, I discuss three recent mobilizations of women against war that have emerged in this broadly-sketched political context: the Camp Casey protest mounted by Cindy Sheehan (and the related work of her organization, Gold Star Families For Peace); CODEPINK for Peace, a women's protest movement founded in the run-up to the Iraq war; and Women in Black, a movement for peace initiated by women in Israel, which has now expanded to the former Yugoslavia, western Europe, and the United States. In each of these cases, I examine the understandings of gender and its relation to antimilitarism that each group advances. I also consider the forms of political engagement each group has adopted and ask how these methods communicate the group's substantive message. In the final section of the paper, I consider whether these rearticulations of the relation between gender and antimilitarism have served antiwar goals, as well as the extent to which they might help to legitimate women's participation in active forms of citizenship.

\section{THREE WOMEN'S ANTIWAR MOVEMENTS}

\section{A. Cindy Sheehan and the Camp Casey Vigil}

Cindy Sheehan's highly visible campaign reflects the first strategy in pairing gender with antimilitarism: basing one's protest against a war effort on literal motherhood. ${ }^{30}$ Sheehan emerged on the political stage after founding an organization of parents of deceased and endangered soldiers called Gold Star Families for Peace following the death of her eldest son, Casey, in Iraq in spring $2004 .^{31}$ Her protest, which highlighted the lack of meaning or direction in the war effort for which her son had died, first came to public attention with a letter to President George Bush following his reelection in 2004. ${ }^{32}$ But Sheehan gained national prominence when she camped out in a ditch (and later on adjoining private property), ${ }^{33}$ across from Bush's ranch in Crawford, Texas,' and declared that she would not leave until Bush met with her, to explain to her the "noble cause" for which her son's life had been sacrificed.34 This monthlong vigil, which was joined by hundreds of other soldiers' families and antiwar protesters, commanded unprecedented media attention and was credited with reenergizing an antiwar effort that seemed to have lost steam after its failure to halt the march to violence in Iraq. ${ }^{35}$

30 See Cindy Sheehan, Peace Mom: A Mother's Journey Through Heartache to ACTIVISM 55-60 (2006) (recounting the author's transformation from "private mother into a public peace mom" after reflecting on her son's death in the Iraq War).

${ }^{31}$ Id. at 108.

32 Id. at 106-09.

${ }^{33}$ Both of these sites were referred to by Sheehan and members of her group as "Camp Casey," in memory of her late son. See id. at 153.

${ }^{34} \mathrm{Id}$. at 136.

35 See id. at 153-201. 
Sheehan makes implicit reference to the claim of the "moral mother": her descriptions of what women learn about the value of life, through their day-today experience with children, ${ }^{36}$ plays some role in her commitment to resisting war. This claim is particularly conspicuous in her later invocations of the term "matriotism." 37 But her earliest and most compelling claims did not invoke the "moral mother" so much as the "suffering mother." 38 Sheehan's claim to knowledge about this war, and her claim to the attention of the nation's leaders, does not arise simply from her motherhood, but from the loss of her son in an ill-conceived war effort. ${ }^{39}$ In an interesting epistemological twist, Sheehan asserts that she is capable of understanding the war effort in a way that the government cannot. She argues that she is entitled to have a voice in policymaking regarding the war because she has "skin in the game" something at stake - which no one in the government has. ${ }^{40}$ She also argues that her experience gives her a distinctive kind of knowledge of the costs of war which needs to be better represented in the policy debate. ${ }^{41}$

${ }^{36}$ Representative examples can be found in several essays of Sheehan's first book. See generally CINDY SHEEHAN, NOT ONE MORE MOTHER'S CHILD (2005).

37 See SHEEHAN, supra note 30, at 212-16 (defining "matriotism" as balancing out the "destructive militarism of patriotism" and referencing the universal nature of motherhood whereby all people have mothers and mothers give life).

${ }^{38}$ See, e.g., Cindy SheEhan, An Open Letter to George Bush, in NOT ONE MORE MOTHER's CHILD, supra note 36, at 3, 3-6 (attacking Bush's handling of the Iraq War with frequent reference to the "hard work" of dealing with her son's death).

${ }^{39}$ See id. Sheehan's appeal to sacrifice as a basis for participation and knowledge is gendered in the first instance because she understands herself as a mother, and sees the rhetorical appeal of saying "not one more mother's child" (perhaps the most immediate way that men deployed as cannon fodder can be humanized and embedded in a web of connection). But also, as the founder of the organization Gold Star Families for Peace, Sheehan makes a similar, yet more gender-neutral claim based on having "skin in the game" (i.e., having sacrificed). See Gold Star Families for Peace, http://www.gsfp.org (last visited May 27, 2007) (describing the group on its homepage as "families of soldiers who have died as a result of war").

40 See SHEEHAN, supra note 30, at 83 (reporting an encounter Sheehan had with Bush in which she reminded him that his two daughters live while her son was killed). A similar claim to knowledge is presented - in somewhat more deferential form - in a letter from the parents of a daughter in the service to George Tenet. See Missy Comley Beattie, Please, Professor Tenet!, http://www.commondreams.org/views06/0506-28.htm (last visited May 27,2007 ) (quoting in full an open letter from parents which states "[y]ou have more of a voice in Washington than we do, but we have more at stake than you do").

${ }^{41}$ See, e.g., Cindy Sheehan, Your Policies Have Created a Hole in My Heart That Can Never Be Filled: Letter to Donald Rumsfeld, in NOT ONE MORE MOTHER'S CHILD, supra note 36, at 43-46 (requesting that Defense Secretary Donald Rumsfeld meet with Sheehan and other family members of soldiers who died to discuss Iraq policy). This implicit claim about the inaccurate assessment of the Iraq war's costs has also been echoed in several other antiwar political interventions in the last year or two. One is The Nation's series War is Personal, an intermittent photoessay contribution that very tangibly illustrates the costs of 
Setting aside these claims to epistemic privilege, Sheehan's invocation of gender is similar in some respects to two other visible protest efforts mounted by mothers: the vigils of the Madres of the Plaza de Mayo in Argentina ${ }^{42}$ and the political activism of the "mothers of martyrs" from the Palestinian refugee camps. ${ }^{43}$ In both cases the authority gained through the protesters' loss of their children creates the platform from which they speak to the government. ${ }^{44}$ The

the war on those who must send, and sometimes mourn, their loved ones. See Eugene Richards, War is Personal (pts. 1-3), The NATION, Mar. 27 - July 10, 2006, available at http://www.thenation.com/directory/bios/eugene_richards (last visited May 27, 2007) (containing various photoessay segments in the War is Personal series, obtainable by searching "war is personal"). A more explicit intervention along these lines was an effort called "Counting the Cost" which was sponsored by Sheehan's organization Gold Star Families for Peace. See CountingTheCost.org, http://www.countingthecost.org/ (last visited Aug. 5, 2007). On May 15, 2005, Americans were asked to wear, on their arms or clothing, large numbers that represented the dead in the Iraq war. See Press Release, CommonDreams.org, New Movement to End U.S. Occupation of Iraq Launches National "Counting The Cost" Event May 15 (May 6, 2005), http://www.commondreams. org/news2005/0506-02.htm (last visited Aug. 4, 2007). The claim underlying these interventions is that a there is a cost not being factored into decision-making in Iraq (and other potential cases of pre-emptive warfare): the cost to those families whose lives are irrevocably transformed by the loss of their loved ones in the conflict. Making this kind of knowledge accessible to the public, who don't have anything so immediate at stake, as well as to those who govern, may play a role in correcting flawed policymaking. This claim was also implicated in a recent conflict between Senator Barbara Boxer and Secretary of State Condoleeza Rice. At a hearing on the President's proposed "surge" in troop strength in Iraq at which Rice was testifying, Boxer called attention to the fact that neither of them had any immediate family relatives who would likely be affected by the government's plans. See Helene Cooper \& Thom Shanker, Passing Exchange Becomes Political Flashpoint Focused on Feminism, N.Y. TIMES, Jan. 13, 2007, at A8. Rice later responded angrily in the press that this question had been an insulting and illegitimate reference to her status as a single, childless adult. See Helene Cooper \& Thom Shanker, Boxer-Rice Exchange Heads to New Arena: Spat at Iraq Dubbed "Womb Wars," CHI. TRIB., Jan. 14, 2007, at C3 (quoting Rice as saying "I thought it was $\mathrm{OK}$ to be single. ... I thought it was OK to not have children").

I would emphasize that this kind of argument - about lack of "skin in the game" and its effect on the estimation of costs in policymaking - is made possible, or made rhetorically credible, by a war effort in which sacrifice is not equalized through the instrument of a draft, and which is being prosecuted by a set of policymakers with little firsthand knowledge of combat, often because of conspicuous efforts to avoid the draft when it was in place.

${ }^{42}$ For a thoughtful account of the Madres' campaign, see Jean Bethke Elshtain, Mothers of the Disappeared, in REPRESENTATIONS OF MOTHERHOOD 74, 74-91 (Donna Bassin et al. eds., 1994).

${ }^{43}$ See generally Julie Peteet, Icons and Militants: Mothering in the Danger Zone, 23 SIGNS 103 (1997) (examining motherhood with reference to Palestinian refugees).

44 See Elshtain, supra note 42, at 84-90 (observing the Madres "[taking] to the Plaza [to] voic[e] their grief and their outrage"); Peteet, supra note 43, at 104 ("With the transition to a highly circumscribed form of autonomy in the West Bank and Gaza in the 1990s, maternal practice and sacrifice have become components for feminist demands for equal rights."). 
similarities between the Madres and Sheehan's Camp Casey occupation also go to the form of the protest action. ${ }^{45}$ In both cases, the protesters claimed a highly visible space (in the Madres' case, it was public space; in Sheehan's it was private property rendered quasi-public - or at least the site of publicity through its proximity to Bush's family compound), and refused to surrender it (Sheehan through continuous occupation; the Madres through regular return), until they received an explanation from the government about the death of their children. ${ }^{46}$ Though the Madres' silent, physically-perilous occupation of the Plaza de Maya had more of the character of witness, and the Camp Casey occupation had a mixed profile that partook of aspects both of carnival and the grinding persistence of Greenham Commons Women's Peace Camp, ${ }^{47}$ the two protests were similar in both analytic structure and in the physical dimension of their demonstration. These protests differed, however, in the relation of the protesters' arguments to claims of citizenship. The Madres confronted one regime that had made war on their children through acts of torture and disappearance, and a successor regime that viewed them as unfortunate victims of atrocities for which they were not directly responsible. ${ }^{48}$ Their children were not lost through any obligation of citizenship that might have buttressed their claim in relation to the government - at most, they were members of the polity whose children's safety should have been secured, rather than imperiled, by the state's leaders. By contrast, Sheehan addressed the government as a mother who had made the ultimate sacrifice in the crucible of intensified wartime commitment, that of her son to the war effort. In that sense, Sheehan's claim to the attention of the government bears more similarity to the "mothers of martyrs" of the Palestinian camps. ${ }^{49}$

As with Sheehan, it is the sacrifice made by the "mothers of martyrs" - the loss of one and often many of their children - that authorizes them to speak to the State ${ }^{50}$ But the nature of the speech these mothers employed renders them somewhat less controversial subjects than Sheehan: they speak from the position of citizens who, notwithstanding their sacrifice, continue to subscribe ardently to the government's goals - in this case the waging of a humanly-

${ }^{45}$ See Elshtain, supra note 42, at 77-78 (showing how the Madres, as in Sheehan's Camp Casey experience, continued a vigil of public protest despite criticism).

${ }^{46}$ See id. (describing the Madres' vigil); see also SHEEHAN, supra note 30, at 153-89 (discussing Sheehan's Camp Casey vigil).

${ }^{47}$ For an illuminating discussion of the Greenham Women's effort, where a group of women kept an protest ongoing over a period of years, see Ann Scales, Militarism, Male Dominance and Law: Feminist Jurisprudence as Oxymoron?, 12 HARV. WOMEN's L.J. 25, 26 (1989) ("I rely in this Article on a particularly hopeful example of feminist intervention in the problem of militarism, that of the Greenham Common Women's Peace Camp in England.").

48 See generally Elshtain, supra note 42.

49 See generally Peteet, supra note 43.

${ }^{50}$ See id. at 104 (arguing that the sacrifices of the mothers of martyrs validated their critique of Palestinian leadership). 
costly, asymmetrical war to secure the creation of a Palestinian state. ${ }^{51}$ Their argument is that their sacrifice entitles them to make a claim on certain resources of the state, including claims for basic support when they have lost the male members of their families, and, sometimes, for inclusion in the policymaking deliberations on questions such as welfare and social service provisions. ${ }^{52}$ The "mothers of martyrs" approach the State with a claim that their sacrifice entitles them to greater political inclusion (a claim which may be complicated by its departure from the more traditional gendered roles that Palestinian mothers occupy), but they approach the State as obedient citizens. ${ }^{53}$. Sheehan, on the other hand, uses her sacrifice as a ground for questioning the entire mission for which her son died, and implicitly challenging the broader claims to knowledge that those who conceived and orchestrated that mission make. ${ }^{54}$ Although her appeal seeks inclusion in a baseline sense - i.e., she wants President Bush to acknowledge her loss and recognize her potential for participation by meeting with her - Sheehan invokes her sacrifice as a call to the government to reverse its policy in a controversial area. ${ }^{55}$ She approaches the State not as an obedient citizen, but as a dissenter in frank resistance to the direction of state policy. ${ }^{56}$ Although neither Sheehan's claim nor that of the "Mothers of Martyrs" may subject them to the dangers facing the Madres of the Plaza de Mayo (several of whom were themselves "disappeared" soon after their vigils began), ${ }^{57}$ Sheehan's claim faces greater challenges in achieving recognition by the government. Historians such as Susan Zeiger have demonstrated with respect to earlier conflicts that while the government ostensibly venerates maternal sacrifice, that sacrifice may be subject to elaborate strategies of cooptation, discipline, or purposeful neglect when it becomes a basis for protest rather than an offering of the obedient subject to the government during wartime. ${ }^{58}$

\footnotetext{
51 See id. at 108-17 (describing Palestinian mothers' participation in national resistance efforts).

${ }^{52}$ See id. at 125 ("Mothers in the camps in Lebanon pressed claims for services on the leadership... [but t]he leadership has been unable to fulfill its promises of financial assistance and services for the families of martyrs.").

${ }^{53}$ See id. at 104 ("Palestinian women, both in Lebanon during the civil war (1975-91) and in the West Bank during the intifada (1987-93), responded to th[e] conflation of mothering with nationalism and acted within its parameter while asserting their own demands and claims on, as well as critiques of, the polity.").

54 See supra notes 30-41 and accompanying text.

55 See supra notes 30-41 and accompanying text.

56 See supra notes 30-41 and accompanying text.

57 Elshtain, supra note 42 , at 82.

58 See supra notes 21-27 and accompanying text.
} 


\section{B. CODEPINK for Peace}

CODEPINK for Peace was formed in November 2002, by Medea Benjamin, Jodie Evans, Starhawk, and other longtime peace, feminist, and human rights activists. ${ }^{59}$ These women staged a four-month vigil in Lafayette Park, across from the White House, hoping to avert the impending war in Iraq. ${ }^{60}$ Of the movements examined here, CODEPINK draws most directly on the image of women as "moral mothers" or "peacemakers." 61 Yet CODEPINK's particular articulation of the connection between women and peace, and perhaps more importantly, its irreverent spirit and direct-action strategies, mark a departure from the sober moralism frequently associated with women's peace activism. ${ }^{62}$

CODEPINK's claim that gender provides a basis for antiwar action wavers between the experiential or practice-based, and the innate or biologicallyessentialist. According to CODEPINK founder Starhawk, "[w]omen have been the guardians of life - not because we are better or purer or more innately nurturing than men, but because the men have busied themselves making war."63 This statement appears to take a purposeful step away from the "moral mother" posture by eschewing a biological or necessary connection between women and antimilitarism. Although this statement doesn't explain precisely how or why "the men have busied themselves making war," it may seem to suggest that war is the product of masculine socialization. Women can therefore provide a distinct, critical vantage point, because they have not been as directly subject to militarist socialization. But as some commentators have pointed out, on discussion boards and other spaces in which CODEPINK has constituted its identity, those who participate in the organization have more readily equated it with the "moral mother" claim. ${ }^{64}$ In some contexts, however, the maternal knowledge CODEPINK claims yields not so much moral insight as practical politics. CODEPINK argues for the redirection of

59 See CODEPINK: About Us, http://www.codepink4peace.org/article.php?list=type \&type $=3$ (last visited May 28, 2007).

${ }^{60}$ Maria Simone, CODEPINK Alert: Mediated Citizenship in the Public Sphere, 16 SoC. SEMIOTICS 345,348 (2006) ("The primary goal at that time was to protest the war with Iraq.").

${ }^{61}$ See CODEPINK: About Us, supra note 59 ("With an emphasis on joy and humor, CODEPINK women and men seek to activate, amplify, and inspire a community of peacemakers through creative campaigns and a commitment to non-violence.").

62 See id.

${ }^{63}$ CODEPINK: Call to Action, http://www.codepink4peace.org/section.php?id=208 (last visited May 28, 2007).

64 See Simone, supra note 60, at 351 ("Despite the [CODEPINK website] claim that women are not 'innately' suited to peaceful activities, the conflation of womanhood with motherhood defies the disclaimer."). But cf. CODEPINK: Call to Action, supra note 63 ("Because of our responsibility to the next generation, because of our own love for our families and communities and this country that we are a part of, we understand the love of a mother in Iraq for her children, and the driving desire of that child for life." (quoting Starhawk)). 
resources into domestic welfare-type policies - or, as their mission statement puts it, "into healthcare, education and other life-affirming activities." 65 CODEPINK activists have also militated for the human rights of those in proximity to the Iraq conflict. They helped to establish the Iraq Occupation Watch to monitor abuses by Americans in Iraq, and demonstrated on the steps of Walter Reed Army Medical Center, where many wounded United States soldiers are treated, to demand enhanced veterans' benefits. ${ }^{66}$ CODEPINK has, in addition, undertaken a range of actions designed to foster human bonds between American and Iraqi citizens, such as accompanying delegations of soldiers' families to Iraq to meet with families there, ${ }^{67}$ or providing fora in the United States for Iraqi women who take a similar stand on the war. ${ }^{68}$ More important in the divergence of CODEPINK from the "moral mother" claim has been the updating of that image through CODEPINK's association with the diffused public sphere of the internet, its "girlie" feminist effort to reclaim femininity, and its culture of consumption and commodification. CODEPINK's website - which contains useful downloadable toolkits for organizing chapters and protests ${ }^{69}-$ not only instructs its members to identify themselves through the wearing of pink accessories, it offers to sell them those accessories, including pink $t$-shirts, underwear, makeup bags, and other accoutrements of the twenty-first century consumer-citizen. ${ }^{70}$ In another departure from the solemnity of the "moral mother" brand of pacifism, CODEPINK takes conventional protest formats (e.g., rallies, demonstrations at political locations like Lafayette Park, etc.), and infuses them with a spirit of direct-action disruption, parody, and guerrilla theatre. ${ }^{71}$ Members have

${ }^{65}$ CODEPINK: About Us, supra note 59.

${ }^{66}$ See CODEPINK: CODEPINK Statement on Vigil Outside of Walter Reed Hospital, http://www.codepink4peace.org/article.php?id=476 (last visited Sept. 22, 2007) (arguing that CODEPINK's efforts "have helped put the spotlight on the needs of the soldiers and helped achieve positive results, such as greater VA funding and a rollback of attempts to make soldiers pay for their own meals, phone calls, daily hospitalization fees and increased co-payments"). A hostile synopsis of the CODEPINK organization containing these and other details may be found through "DiscoverTheNetwork.org," a self-described "Guide to the Political Left." See Description of Code Pink for Peace, http:/www. discoverthenetworks.org/printgroupProfile. asp?grpid=6149 (last visited May 28, 2007).

67 See id.

${ }^{68}$ See CODEPINK: Support Iraqi Women, http://www.codepink4peace.org/article.php? list=type \&type=131 (last visited Aug. 6, 2007) (describing CODEPINK's effort to bring "a delegation of Iraqi women to the U.S. for March 8, 2006, International Women's Day, as part of the Women Say No to War campaign").

${ }^{69}$ CODEPINK: Local Group Resources, http://www.codepink4peace.org/section.php? id $=78$ (last visited May 28, 2007).

70 CODEPINK: CODEPINK Store, http://www.codepinkalert.org/catalog (last visited May 28, 2007).

71 On the subject of CODEPINK's direct-action, ACT-UP-style mode of operation, the mission statement proclaims: "We reject the Bush administration's fear-based politics that 
dropped their pants on cue to reveal dove-emblazoned undergarments, ${ }^{72}$ and they have given "pink slips" (oversized items of lingerie) to officials who have violated the public trust through war-related actions. ${ }^{73}$ In a strategy that borrows liberally from the innovations of groups such as ACT-UP, CODEPINK's public interventions may be aimed as much at mobilizing civil society as at persuading specific political actors. ${ }^{74}$

\section{Women in Black}

Women in Black is a movement started in Israel in 1988, to protest the Israeli occupation of the West Bank and Gaza. ${ }^{75}$ Its minimalist, symbolic mode of protest has been taken up by women in the former Yugoslavia, western Europe, and the United States. ${ }^{76}$ Women in Black resembles CODEPINK in that it is a network of loosely-related mobilizations, and it resembles both of the previous movements in deploying gender to resist various forms of militarism. But Women in Black is also distinct from those examples because of the radical way that it invokes gender in its reconstruction of citizenship.

Women in Black's first vigil, which has since been repeated every Friday afternoon in a public square in Jerusalem, created and epitomized its strategy. ${ }^{77}$ A group of women, ranging from several dozen to more than a hundred in number, dressed in black and carrying signs with the simple message "Stop the Occupation," stood together quietly for one hour each week, at the same time and place, for six years. ${ }^{78}$ The demonstration's "minimalism" was a central,

justify violence, and instead calls [sic] for policies based on compassion, kindness and a commitment to international law. With an emphasis on joy and humor, CODEPINK women and men seek to activate, amplify and inspire a community of peacemakers through creative campaigns and a commitment to non-violence." CODEPINK: About Us, supra note 59. For an example of work connecting CODEPINK to the direct-action innovations of ACTUP, see Lucas Hilderbrand, Retroactivism, 12 GLQ: J. LESBIAN \& GAY STUD. 303, 312 (2006) ("Feminist . . groups, such as . . Code Pink have also continued ACT UP's camp strategies.").

72 Starhawk, A Code Pink Diary (Oct. 2, 2002), http://www.starhawk.org/activism/ activism-writings/codepink.html (last visited Aug. 7, 2007) ("We march up to the steps [of the United States Capitol], unfurl a banner. Several members of our team strip down to dove-covered bras and underwear, and we begin our radical cheer ....").

${ }^{73}$ See Description of Code Pink for Peace, supra note 66.

${ }^{74}$ See supra note 71.

75 See Sara Helman \& Tamar Rapoport, Women in Black: Challenging Israel's Gender and Socio-Political Orders, 48 BRIT. J. Soc. 681, 683 (1997) (explaining the beginnings of the Women in Black movement).

${ }^{76}$ History of Women in Black, http://www.womeninblack.org/history.html (last visited May 28, 2007) (detailing the international spread of the Women in Black organization from its original roots in Israel).

77 See Helman \& Rapoport, supra note 75, at 683-84.

${ }^{78} \mathrm{Id}$. 
purposive feature of its mode of protest. The women stood persistently behind their one-sentence message, supplemented occasionally by an "identity card" which explained:

The protest vigil is an expression of Israeli society and expresses our need to actively and strongly oppose the occupation. We are women of different political convictions, but the call to "Stop the Occupation" unites us. We all demand that our government take immediate action to begin negotiations for a peace settlement. Many of us are of the opinion that the PLO is the partner for peace negotiations based on the principle of two states for two peoples, while others are of the opinion that it is not for us to decide who the Palestinian partner for negotiations is nor the exact solution on which peace should be based. We are unified in our belief that our message is powerful and just and will eventually bring peace. ${ }^{79}$

This minimalist message, which participants consistently declined to elaborate, permitted each woman to maintain her own reasons for opposing the occupation without disturbing the unanimity and legibility of the group's message ${ }^{80}$ It also obviated the need to invest time and energy in a deliberative process aimed at clarifying and articulating the group's ideological framework. ${ }^{81}$ This unusual absence of deliberation made sense within a strategy that was aimed less at negotiating understandings among participants and more at challenging the assumptions of those who observed the vigils. Central among these assumptions, of course, was the morality and the political value of the continued occupation of the territories. ${ }^{82}$ But Women in Black also took aim at the meaning of gender in Israeli society and its relation to conventional understandings of citizenship. ${ }^{83}$

The protesters stood together as women, and their silent wearing of black reflected the mourning function frequently assigned to women in war-torn societies. While these attributes inevitably produced what Joan Scott has called "reverberations" 84 of the conventional image of the "moral mother" or the "mourning mother," the most salient elements of the movement's symbolism confront rather than reinforce traditional Israeli understandings of gender. First, in a culture in which women are strongly identified with their

79 Id. at 684.

${ }^{80} \mathrm{See}$ id. at 689 ("The women became increasingly aware that if ideological conflicts were allowed to surface, the group would quickly disband.").

${ }^{81}$ See id. at $687-89$ ("[P]articipants were motivated by a desire to avoid any deliberation that could endanger the continuity of the demonstration.").

${ }^{82}$ See id. at 683 (highlighting the Women in Black's disagreement with the occupation).

${ }^{83}$ See id. at 694-96 (discussing the broader implications on gender understanding and the sociopolitical order that the Women in Black's demonstrations created).

84 Joan Wallach Scott, Feminist Reverberations, Differences: J. Feminist Cultural STUD., Fall 2002, at 1, 11-12 (describing "reverberations" as causes of regression, re-echoes, and repercussions that characterize modern circuits of influence). 
familial roles, the Women in Black did not invoke any familial connection. They did not present themselves as mothers, sisters, or daughters of warriors, or potential warriors - though some of them doubtless understood their own participation in relation to such roles. ${ }^{85}$ While their dress reflected mourning for the Israeli dead, the group's professed mourning for the tragedy of Palestinian loss dispelled that conventional interpretation; indeed, it made these women's claims to citizenship contentious for some observers. ${ }^{86}$ In addition, the women's decision to stand in public protest at a time when women are expected to be at home preparing the family for the Sabbath conspicuously detached them from familial and religious gender roles. ${ }^{87}$

Women in other war zones, such as Kosovo, as well as antimilitarist movements in many western democracies, have adopted this same strategy of protest: silent, weekly vigils by women in dark clothing offering a simple message of dissent. ${ }^{88}$ In some cases the resistance has targeted a slightly different object, or has been articulated in brief, collective statements, while in other cases joint vigils held by women from opposing sides of a conflict have challenged entrenched antipathies and offered a view of citizenship only loosely bound to state or nation. ${ }^{89}$ The shared symbolism and mode of protest, and the minimal elaboration of the substantive message, has made Women in Black a flexible vehicle for addressing a range of militarized conflicts. ${ }^{90}$ It has also produced, as Joan Scott has argued, a gendered challenge that is variable in its content and responsive to context - a mobile, non-unitary political

85 Helman and Rapoport quote one participant interviewed as saying:

I'm standing in protest because of my sons .... What do I care [if] one woman is out there because of her feminism, and another wants to prove to the male dominated society that women can and men can't [maintain a protest over a long period of time] ... and another loves the Palestinians because they are human beings and she wants them to live like us? What do I care why they're out there? .. . The truth is, I never looked into the matter too much.

Helman \& Rapoport, supra note 75, at 687.

${ }^{86}$ Helman and Rapoport note that many of those jeering at and harassing the Women in Black in Jerusalem assailed them as traitors, or as the agents - or sexual partners - of the Palestinians. Id. at 690 (explaining that these insults emphasized "that the women serve not only the common Palestinian, but his leader as well").

${ }^{87}$ Id. at 691 ("According to the drivers' interpretation, the very act of standing in the street on Friday afternoon constitutes a disruption of the gender-based division of labour and thus of the natural-cosmic order of gender roles.").

88 See supra note 76 and accompanying text (describing the spread of Women in Black's protest model to the former Yugoslavia and other countries).

89 See Scott, supra note 84, at 16-19 (describing the varied efforts of Women in Black organizations in western Europe and the former Yugoslavia, including efforts to end interethnic conflict).

${ }^{90}$ See id. at 19 ("[Women in Black's] existence as 'a means of mobilization and a formula for action' presumes fundamental differences among feminists, differences of context, differences of history, differences of understandings of the feminine and of feminism itself."). 
performance that eludes reductive characterizations and renders gender, as a category, perpetually under construction. ${ }^{91}$ Yet the same minimalism that permits strategic adaptation and resists stereotyping may render Women in Black's message opaque or ambiguous, or clearer in some contexts than others, a point to which I return later.

\section{REARTICULATING GENDER, RECREATING CITIZENSHIP}

What do these movements suggest about the renegotiation of gender, at this vexed political moment, and its potential for forging new claims of citizenship for women? I will argue that each of these movements reflects, to greater or lesser degree, a politics of articulation: they highlight, and seek to employ to advantage, conventional attributes of gender that might justify a claim to oppose the government's war; yet each movement combines these conventional elements with less familiar and more discordant ways of articulating gender, to create new political roles and new kinds of gendered images or subjectivities. In so doing, each uses non-violent, direct-action techniques - including particular deployments of their participants' physical bodies - in ways that innovate, even as they resonate with more familiar protest strategies. These disparate practices provide a basis for assessing women's ability to mobilize - from an explicitly gendered position - an antiwar protest. They also shed light on what I have argued is the inevitable subtext in any political effort involving women: women's effort to demonstrate their potential as full citizens, by participating actively and substantively in the varied processes of self-government.

\section{A. Gender and the Body Politic}

Each of these efforts reflects a depiction of gender: a subtle mixture of the conventional - on which an appeal to leaders might be made - and the dissonant, conveying the participants' own, more complex sense of gendered political identity. These combinations, or re-articulations, produce particular images of the resistant, gendered citizen - an image that is different for each of the protest movements discussed above. Part of this imagery arises from the subtle and creative deployment of the bodies of the women involved. Directaction, protest politics is often a bodily affair: participants choose to put their bodies "on the line" in some way, rather than (or as well as) engaging in more conventional, verbal forms of protest. But the bodily aspect of these particular protests goes beyond the choice of direct-action strategies: each of these efforts is noteworthy for the use it makes of the gendered body - the way that it deploys, challenges, or attempts to rearticulate images of the body that are distinctly associated with women and femininity. Given the salience of women's bodies in our culture, this dimension of gendered protest presents a

${ }^{91}$ Id. at 17 (describing the Women in Black's method as a "formula for action" with an aim that "varies depending on the political context the women have chosen to address"). 
unique - if inevitably complicated - opportunity to seize public attention, and to project images that may contribute to women's claims as dissenters, and, more broadly, as citizens.

\section{The Angry Mother}

Cindy Sheehan's appeal to President Bush links maternal suffering not with patriotic obedience, but with indignation and anger. ${ }^{92}$ If, as some analysts have suggested, ${ }^{93}$ one knows a protester by the terms in which she is derided by her critics, it should not be surprising that Sheehan is targeted for the immoderacy and profanity of her language. Sheehan has remained largely unrepentant in her colorful vehemence, ${ }^{94}$ arguing that no one has better reason for extreme language than a mother who has lost her son in a meaningless assertion of political will. ${ }^{95}$ But the repeated critique of Sheehan's intemperate speech testifies to the discomfort and lack of familiarity among members of the public with the angry mother - and to the potential of this image to claim the attention of a media- and message-saturated citizenry. The angry mother is startling and unseemly, yet also forceful. Her bluntness and vehemence are striking in their discord with traditional conceptions of maternal virtue; yet at the same time the strength and perseverance in the angry mother's stance resonates with more traditional images of maternal protection and care.

Sheehan brings power and gravity to her assertion of maternal anger through her use of her physical body. In some ways, Sheehan's use of her body is consistent with earlier, gender-neutral forms of non-violent protest: she sits, she strikes, and she subjects herself to arrest. But in other ways, Sheehan's

92 Although I focus here on the gendered aspects of Cindy Sheehan's protest and citizenship, there is also an interesting respect in which her appeal is not conspicuously gendered. Sheehan identifies herself as a mother, but her image is also that of a kind of "everyman" - or "every-bereaved-parent." She is not of elite socioeconomic status, and she is neither unusually articulate nor particularly photogenic. She is most conspicuously injured, angry, and persistent, and she explicitly shares her status with the parents and families of dead and injured service members of all sexes, races, and ethnicities, both rhetorically and through her organization, Gold Star Families for Peace. These attributes cause her appeal to extend beyond gender or maternalism, and may account to some degree for her success in garnering national attention.

93 See Helman \& Rapoport, supra note 75, at 689-94 (analyzing the insults leveled at the Women in Black of Jerusalem and the ways in which those insults indicate that the Women's protest challenges the existing social order).

${ }^{94}$ In her testimony before the Congressional Forum on the Downing Street Memo, Sheehan comments purposefully that she has reined in her expression out of respect to the Members of Congress. CINDY SHEEHAN, Testimony Before the Congressional Forum on the Downing Street Memo (June 16, 2005), in NOT ONE MORE MOTHER's CHILD, supra note 36, at 58, 63 (2005) ("Mr. Conyers, out of my deep respect for you, the other representatives here, my fellow witnesses, and viewers of these historic proceedings, I was able to make it through an entire testimony without using any profanity.").

95 Id. at 63 ("However, if anyone deserves to be angry and use profanity, it is I"). 
methods of protest seem to challenge gendered assumptions about the presentation or deployment of women's bodies, in politics and elsewhere. Women in American culture do not traditionally occupy land - particularly private and quasi-public property which is not theirs - immediately adjacent to the homestead of the leader of the free world. Sheehan did this, riveting the nation's attention to her effort. ${ }^{96}$ There is also something subtly unconventional about Sheehan's presentation of her own body - her own physical form - in these protests. Sheehan is a large, plain, and rather awkward woman: she repeatedly delivers up this unadorned physical form as a kind of symbol of her cause. Her apparent lack of self-consciousness about her physical appearance, as she stands next to Charlie Sheen, Susan Sarandon, and a host of other celebrities, politicians, and protesters is at first unremarkable. But her lack of pretense, or of (ostensibly) feminine vanity, in serving up her unadorned physical form - which directly parallels her lack of selfconsciousness in sharing her most intimate grief with the nation's leaders and citizens - comes, through repetition, to feel like a pure assertion of political will.

Sheehan is also resolute in her willingness to sacrifice virtually all forms of physical comfort in her occupation at Camp Casey. Her journals, perhaps not coincidentally, read a bit like the wartime journals of a new recruit: they are full of the discomforts and privations of a life lived in the heat and dirt, in constant, uneasy readiness for the next confrontation. ${ }^{97}$ They also tell of the laryngitis and fevers she suffers ${ }^{98}$ as she mobilizes her allies, negotiates with state troopers, and undertakes dozens of interviews a day. Yet Sheehan is absolutely undeterred from her path, finding hope in this chaos and privation, rather than discomfort or despair..$^{99}$ In one sense this posture may make Sheehan the paradigmatic mother: instinctively denying her own bodily comfort to achieve a larger goal. But the contexts in which she performs this bodily self-effacement are so distinct from the more familiar contexts of

96 Sheehan has also used a portion of the proceeds from her son's life insurance policy to purchase a five-acre plot of land in Crawford, Texas, another unconventional form of selfassertion for a woman. See generally Jack Douglas, Jr., Sheehan Buys Plot in Crawford with Son's Insurance Money, FORT WORTH STAR-TELEGRAM, July 27, 2006.

97 See, e.g., SHEEHAN, supra note 30, at 155 ("We didn't have to immolate ourselves, we just had to endure twenty-six days of heat, fire ants, thunder-and-lightning storms, and constant attacks to bring our cause to the attention of mainstream America, and people were paying attention.").

98 See id. at 174 ("I had a fever and a horrible sore throat and my heart was broken by my dear friends coming and trying to fix a situation that wasn't broken, and taking what was working so well and trying to mold it into their idea of what a peace camp should look like.").

99 Cindy Sheehan, From Despair to Hope, in Not One MORE Mother's ChILD, supra note 36, at 193, 196 ("I had thought all my hope was KIA the day Casey was KIA.... Camp Casey, with its wonderful feelings of love, acceptance, peace, community, joy, and, yes, optimism for our future, gave me back my desire to live."). 
motherhood - the night feedings or the ministrations to the sick - as to render this self-denial at once more powerful and more oriented toward public goals.

\section{The Gendered Direct-Action Performer}

As a large, diffuse network of organizations, CODEPINK has, in some respects, less capacity to project a coherent image, gendered or otherwise. Yet this group - which is most conspicuously the product of an internet-assisted, mass-mediatized culture - seems most concerned with projecting a gendered image, or experimenting with gendered representation, as it communicates its antiwar message. CODEPINK draws on the familiar image of the "moral mother," who protects life against the ravages of war, but it articulates this image using less familiar and apparently incongruous elements of gendered identity. The semi-parodic embrace of the color pink and elements of consumer culture (e.g., the sale of pink T-shirts and other accessories as both a fundraising strategy and a style or sensibility) ${ }^{100}$ reflects elements of "thirdwave" or "girlie" feminism: the effort to reclaim the stereotyped elements of conventional femininity, in a spirited and conspicuously agentic manner. The panty-baring, traffic-stopping, pink-slipping tactics of the movement also mirror the irreverent and intentionally "outrageous" direct-action performances of groups such as ACT-UP. ${ }^{101}$

The incongruities that CODEPINK avidly cultivates are made tangible on the bodies of participants. Pink, paraphernalia, and purchasing may evoke the stereotype of the pampered, physically-adorned woman. Yet this woman subjects her body to physical dangers, whether by hunger-strikes, or by crossing the Golden Gate bridge during rush-hour traffic. ${ }^{102}$ And amidst her pink attire, this woman flaunts traditional feminine modesty by dropping her pants and carrying oversized lingerie through the streets. These incongruities exceed - even as they evoke - the cheerful, purposive contradictions or "girlie" feminists. ${ }^{103}$ They project a paradoxical yet vehement image of citizenship: one in which improvisation aims at maximizing impact and reanimating politics; one in which proliferation, of activities and of personae, signals singularity of political will; and one in which exaggerated femininity - long

100 See supra notes 69-70 and accompanying text.

101 See supra notes 71-74 and accompanying text.

102 See Mark Prado, Code Pink's War Protest Jams Bridge Traffic, MARIN INDEP. J., Sept. 22, 2006, available at $\mathrm{http}: / / \mathrm{www} \cdot \mathrm{marinij.com} / \mathrm{marin} / \mathrm{ci} 44378700$.

103 For representative third-wave works, see generally JENNIFER BAUMGARDNER \& AMY Richards, Manifesta: Young Women, Feminism, and the Future (2000); Colonize THIS!: YOUNG WOMEN OF COLOR ON TODAY'S FEMINISM (Daisy Hernandez \& Bushra Rehman eds., 2002); To Be Real: Telling the Truth and Changing the Face of FEMiNISM (Rebecca Walker ed., 1995). For works that draw on the pro-(hetero)sex, powerclaiming dimensions of "girlie" feminism, see generally KATIE ROIPHE, THE MORNING After: Sex, Fear, and Feminism on Campus (1993); NaOmi Wolf, Fire with Fire: The NEW Female POWER AND How to USE IT (1994). 
read as the sign of apolitical triviality - is married to daring and committed public engagement.

\section{The Woman as Witness}

Women in Black constitute themselves as a gathering of women, yet persistently refuse the conventional associations that gender invokes. They decouple themselves stringently from familial associations, declining also the validating aura that religious practice confers upon women in Israeli society. Even their failure to elaborate their message refuses the communicative skills, and interpersonal engagement, which have been claimed by women as their distinctive terrain. Moreover, by appearing in public shorn of validating affiliations, Women in Black also refuse the subsidiary or indirect role that has been accorded them in Israeli politics: in departure from long tradition, they participate neither as wives, nor as mothers, nor as supporters of combatants. In their well-orchestrated silence, they speak prominently, and audibly, for themselves.

The politics of refusal performed by Women in Black extends also to their physical self-presentation. In one sense their strategy is the denial of the body: in concealing, monochrome black clothing, the distinctiveness of the protesters' bodies, as women, and as individuals, is erased. There is not a hint of sexuality to this gendered presentation; the hecklers' jeer, that they are the prostitutes of the Palestinians, seems to stem more from an impoverishment of political vocabulary ${ }^{104}$ than from any invocation of gendered sexuality. Yet this protest is, nonetheless, enacted by women; and through it they have chosen to place their bodies in a highly visible public forum. Without a detailed message, the simple presence of their stark and simply-clad bodies becomes more conspicuous. The austerity of their plain black clothing, coupled with the confrontation of their silent, bodily presence, creates a powerful and demanding image of witness, one whose strangeness and intensity of focus demand an answer. The appearance of women without words, family connections, or the comfortingly familiar, compliant, gendered presentations of the body, taps into an unsettling (albeit unrealized and perhaps unrealizable) image of undomesticated female power. This image illustrates what women might become if they could hold themselves apart from dominant, feminizing influences and call the world to account.

\section{B. Gendered Antiwar Protest and Political Efficacy}

The first question to ask is whether these movements' novel rearticulations of gender achieve the authority for, and success in, antiwar protest that they seek. In some respects, the answer is equivocal. These movements have

104 Unable to assimilate them to the mold of the Madonna, hecklers turn immediately to that of the Whore. For an interesting discussion of the hecklers' attacks on the Jerusalem Women in Black, see Helman \& Rapoport, supra note 75, at 690 (describing the aggressive and sexist hand gestures and explicit sexual references directed at the protesters). 
suffered a significant degree of backlash: Cindy Sheehan has been excoriated for neglecting her surviving children, ${ }^{105}$ and for her alternately blunt and profane modes of public address; ${ }^{106}$ the Women in Black have been the subjects of elaborate public heckling, and have been reviled as the "whores of the Palestinians." 107

Perhaps more importantly, there are also questions about whether these rearticulations have effectively communicated their proponents' messages, or even helped to constitute the authority to which their proponents aspire. As Sheehan's example suggests, the same maternal role that may seem to authorize protesters may also make them vulnerable to the disciplinary tactics of their critics. ${ }^{108}$ Although the role of the mother may be culturally understood to entail determination and even ferocity in the protection of her young, ${ }^{109}$ the maternal role is also associated with an acute awareness of the demands of convention and hierarchy that can militate against this fierce defensive impulse. Mothers perform their roles within an institution that has been notoriously hierarchized from within ${ }^{110}$ and disciplined from without, ${ }^{111}$ and many mothers perform their role in ways that accommodate or manage the demands of that hierarchy, rather than subvert or contest it. Moreover, as philosopher Sara Ruddick argues, a central attribute of the maternal role itself is the preparation of one's children to conform sufficiently to the conventional norms and expectations of society by appropriately relating to others in interpersonal, social, and professional interactions. ${ }^{112}$ These attributes can make mothers (as incipient political protesters) both subject, and particularly vulnerable, to government manipulation or public criticism that associates resistance with bad mothering, and acquiescence with good mothering. Susan

105 See SHEEHAN, supra note 30, at 124-25.

106 See supra notes $92-95$ and accompanying text.

107 See supra notes 86-87, 104 and accompanying text.

108 There may be yet another tension inherent in the implicit or explicit association of motherhood with an inclination toward, or distinctive appreciation of, peace. While the protesting mother may have a unique perspective from which to critique war-making, this same perspective may position her so far from the expertise involved in making war as to discredit her claims. This may be one reason that Cindy Sheehan's claim of having a kind of expertise about the costs of war (the "skin in the game" argument), which government decision-makers lacked, had at least some degree of rhetorical purchase.

109 This attribute is sometimes captured in the American English vernacular as the "mother bear" response to a danger to her young.

110 See Susan Moller OKin, Justice, Gender, AND the Family 4 (1989) (arguing that there is a "cycle of power relations and decisions [that] pervades both family and workplace, each reinforcing the inequalities between the sexes that already exist within the other").

111 See FinEmAN, supra note 29, at 101-06 (arguing that the designation of single mothers as "deviant" is part of a system through which patriarchal control is asserted over women and children).

112 RUDDICK, supra note 25, at 103-23 (arguing that an important part of a mother's role is in training her children to effectively operate in the world). 
Zeiger's study of the ultimately successful propaganda campaign launched against "selfish" maternal resistance to World War I reveals this tendency. ${ }^{113}$ Cindy Sheehan's critics made a similar effort to curtail her Camp Casey protest by highlighting her husband's filing for divorce, and suggesting that she was neglecting her living children by maintaining her vigil. Sheehan, through resolute candor about her family situation, ${ }^{114}$ was largely able to surmount such criticisms; but they remain a potent means of disciplining the dissenting activities of mothers.

Less conventional, or more hybrid maternal images also have their perils, as the experience of CODEPINK suggests. One study of CODEPINK notes that the public perceives the organization as foregrounding women's femininity; but is otherwise uncertain about its substantive position. ${ }^{115}$ One can question, as this study seems to, ${ }^{116}$ the success of CODEPINK's paradoxical strategy, and whether its performance will be read in the way that its ambitious proponents hope.

The problem, as I see it, does not lie in the performance-oriented, directaction strategy in and of itself. Parody and guerrilla theatre as responses to the meaningless sacrifice of human life were staples of Vietnam War protest. ${ }^{117}$ And ACT-UP, the protest movement whose strategies CODEPINK most conspicuously borrows, pioneered the use of parody and outrage to protest meaningless, unnecessary deaths born of misguided governmental policy. ${ }^{118}$ Yet context in such rearticulations is everything, and there may be important differences between ACT-UP and CODEPINK in this regard. The strategy of confronting tragedy with irreverence or parody may work best when one has, as Cindy Sheehan puts it, "skin in the game." Many of ACT-UP's activists

113 See Zeiger, supra note 21, at 7-8.

114 See SheEhan, Day Ten: Leave My Family Alone, in Not One More Mother's CHILD, supra note 36, at 99, 99-100 (confronting public criticism of Sheehan's troubled family situation and claiming such matters are "between my husband and me").

115 See Simone, supra note 60, at 357-59 ("Two patterns emerged in the analysis of these [mainstream news] articles [about CODEPINK]. First, journalists recognized the group's gender identity, and often framed this identity in terms of traditional femininity. Second, journalists emphasized the group's extremist actions while frequently ignoring their political positions.").

116 See id. at 360 ("[T]he public credibility afforded by the mainstream media is ambivalent at best. The media identifies CODEPINK as relevant by selecting it as a topic. Yet, the simplified and polarized coverage calls into question whether this group has yet received acknowledgement as reasonable and respectable.").

117 See, e.g., NICOSIA, supra note 17, at 56-67 (describing Operation RAW, a massive 1970 guerrilla theatre procession between Morristown, New Jersey and Valley Forge, Pennsylvania).

118 See Hilderbrand, supra note 71, at 303-04 (describing ACT-UP's pioneering use of video to protest official policies regarding the HIV/AIDS epidemic). 
were facing painful and imminent death as a result of governmental policies. ${ }^{119}$ Distributing oversize pink slips and "dropping trou" in public settings may resonate when the protesters' own lives are not immediately placed in danger by the government's persistence in misguided action. These protests may also have a different resonance when they are combined with pink accessories and consumerism. There is a precarious, unstable line between self-parody as rearticulation and the re-inscription or reinforcement of dominant (and stigmatizing) discourses. It is hard to know where the activities and imagery of CODEPINK lie in relation to this line. This problem is complicated, of course, by the fact that the organization is a very loose alliance of hundreds of local groups, each running its own events and performing its own version of CODEPINK gender and citizenship.

A strategy that involves minimalist invocations of gender, such as that deployed by Women in Black, permits its adaptation to a range of political contexts, ${ }^{120}$ but seems likely to be more effective in some settings than in others. In Jerusalem, the abrupt departure from gender roles implicit in standing in a public square shortly before the Sabbath marked these women as gender outlaws, and contributed a weight born of strangeness and unfamiliarity to their efforts even as it outraged some passers-by. ${ }^{21}$ In my hometown of Berkeley, where a group of Women in Black also assembles every Friday near Sproul Hall (site of the "free speech" protests), the message is different. There is little that is surprising about seeing a group of women assembled in a public space there; given the secularity of the surrounding culture, there is nowhere else one would expect women to be at that time. Although they are dressed similarly in black, the protesters' appearance offers a monochrome take on the usual sartorial choices of middle-aged women in Berkeley. Moreover, they stand with banners that are not decisively different from those of other protesters. And, far from commanding the public space, they share the square with an extraordinarily heterogeneous group of protesters - campus Republicans, pro-immigration activists, animal rights advocates, and a number of persons with mental illness who have set up soapboxes and struggle publicly with their own demons. Women in Black has projected a potentially useful image of women as witnesses - women whose distance from the socialization and current discourses that support war permits them to offer a critique. But it may be worth asking whether this minimalist performance is likely to be lost in a message-saturated culture such as the United States. One might also wonder whether rejecting the traditional indices of gender in claiming citizenship - a strategy that was highly effective in Israel - will be as salient in cultures where gender expectations have become less rigid and singular, where women

119 See id. at 312 ("ACT UP's actions seem more personal, more immediate than recent activism: after all, the protesters frequently were fighting for their lives.").

120 See Scott, supra note 84, at 17-18 (describing Women in Black's protests in Israel, Belgrade, and the United States).

121 See supra note 87 and accompanying text. 
regularly claim citizenship without presenting themselves as mothers, sisters, daughters, or other supporters of men.

\section{Gendered Antiwar Protest and the Paradoxes of Women's Citizenship}

A second question for analysts of women-led protest movements, as well as for protesters themselves, concerns women's longer-term aspirations as political actors. Movement toward the political mainstream entails perils for many protest movements; even modest efforts in this direction may diffuse or compromise resistant politics. ${ }^{122}$ Yet for women, who remain in important ways at the threshold as political actors, the implications of protest activity for broader acceptance as citizens is a question that demands awareness and careful reflection, even if it does not conclusively shape activists' priorities. ${ }^{123}$ A form of protest that is equivocal for purposes of anti-war resistance may be more problematic if it impedes women's efforts to gain legitimacy as active citizens.

The instances of resistance, neglect, and devaluation women-led antiwar groups have confronted might give reason for doubt. They may confirm that many of the central images of citizenship, civic participation, and dissent remain indicatively masculine: from the freedom from the quotidian tasks of bodily care that Athenian (or early American) citizens enjoyed, to the individualism and independence of the Emersonian dissenter, to the particular forms of gravitas associated with historical icons of civil disobedience. ${ }^{124}$ They suggest that these same roles, when women perform them, might not

${ }^{122}$ For thoughtful discussions of these tensions in the context of the pro-choice movement, for example, see generally Myra Marx Ferree, Resonance and Radicalism: Feminist Framing of the Abortion Debates of the United States and Germany, 109 AM. J. SoC. 304 (2003); Suzanne Staggenborg, The Consequences of Professionalization and Formalization in the Pro-Choice Movement, 53 AM. SoC. REv. 585 (1998).

${ }^{123}$ Clearly women protesters must worry about the substance and institutional focus of their challenges as well as the gendered imagery they deploy. Many supporters of Cindy Sheehan, for example, believe that she made a crucial miscalculation when she proposed to move from protest to electoral politics by challenging the seat held by House Speaker Nancy Pelosi. See, e.g., Posting of Katha Pollitt, Dear Cindy: Please Don't Run, to The Nation, Blog: And Another Thing, http://www.thenation.com/blogs/anotherthing?pid=222380 (Aug. 11, 2007, 20:19).

${ }^{124}$ Consider the fairly uniform maleness of these icons, at least as they are understood in American culture, including Thoreau, Gandhi, and Martin Luther King. Of course there have been women who have practiced civil disobedience and exhibited qualities of gravitas, whether the same or different from these examples - Sheehan herself might be an example and there have been interesting efforts by feminist scholars and even novelists to depict these attributes of female civil disobedience. See Scales, supra note 47, at 26-27 (describing a 1981 protest march from Cardiff, Wales to Newbury, England that became a permanent encampment protesting NATO's decision to deploy cruise missiles nearby). See generally MARY GORDON, PEARL (2005) (providing a fictional account of an American woman who chained herself to the American Embassy in Ireland during the final throes of a hunger strike). 
have the same immediate cultural resonance as the mixed public response to Cindy Sheehan's indignation and anger suggests. ${ }^{125}$ But these difficulties do not, in my view, suggest the self-conscious invocation of gender - such as that undertaken by these movements - is inevitably damaging to women's longterm prospects as citizens. Each of these strategies for asserting gendered citizenship has distinctive dangers. But each may also have something to offer women over the long run, particularly if deployed with care and admixed with other, non-gendered forms of civic imagery and participation.

Conventional maternal claims to knowledge have cultural resonance, but also distinctive risks. The public/private divide invoked by women's claims to maternal knowledge has had extraordinary salience in the history of women's equality, and it is an obstacle on which even legal efforts to enact women's equality have often foundered. Reva Siegel has demonstrated that the Nineteenth Amendment won passage because its proponents succeeded in refuting a range of claims about the subordinate role of women in households, the central value of harmony in the family, and the primacy of state law in regulating familial relationships. ${ }^{126}$ Yet once the Amendment was enacted, it was narrowly interpreted to secure a formal right to vote to women; perhaps more importantly, those proffering this interpretation consistently declined to contest traditional understandings of women's familial roles. ${ }^{127}$ Moreover, Martha Fineman and Joan Williams have argued that the failure to negotiate the public/private divide has circumscribed legal change in the market realm as well. ${ }^{128}$ Employment discrimination laws, such as Title VII, have been

${ }^{125}$ Philosophers as diverse as Martha Nussbaum and Marilyn Frye have described the emotions of anger and indignation as particularly suited to the public realm. See Marilyn Frye, $A$ Note on Anger, in The Politics of Reality: Essays in Feminist TheOry 84, 93 (1983) ("Contemporary feminists have taken on the more radical project of expanding the concept of Woman to the point where a woman can assert herself and make demands upon respect, in public or private, simply in her own behalf."); Martha Nussbaum, "Secret Sewers of Vice": Disgust, Bodies, and the Law, in ThE PAssions of LAw 19, 26 (Susan A. Bandes ed., 1999) ("It has been frequently remarked that indignation rests on reasons that can be publicly articulated and publicly shaped."). Yet when this anger is manifested by women as protesters, it prompts a more equivocal response.

126 See Reva Siegel, She the People: The Nineteenth Amendment, Sex Equality, Federalism, and the Family, 115 HARV. L. REV. 947, 977-1006 (2002) (discussing arguments against ratification of the Nineteenth Amendment based on women's role in the private sphere and the role of state law in a federal system of government).

127 See id. at 1012 ("Soon after ratification, the judiciary moved to repress the structural significance of women's enfranchisement, by reading the Nineteenth Amendment as a rule concerning voting that had no normative significance for matters other than the franchise.").

128 See FINEMAN, supra note 29, at 161-64 (arguing that the allocation of the burden of caring for dependants to the private sphere, and specifically to women, is responsible for women's limited success in achieving equality within the public sphere); Joan C. Williams, Deconstructing Gender, $87 \mathrm{MICH}$. L. REv. 797, 822-36 (1989) (arguing that traditional conceptions of men as belonging in the public, wage-earning sphere and of women as 
successful in incorporating women into most workplaces, but their failure to reallocate, restructure, or subsidize familial labor has limited their effects on gender integration in the workplace. ${ }^{129}$ The public/private divide conjured by women's maternal role has been a particular, persistent force in limiting women's equal civic participation and membership in a variety of realms outside the home.

But to acknowledge these complications is not to reject maternal claims across the board. Attempting to legitimize one's participation in antiwar politics - or one's broad engagement in a range of political topics - through generalized invocations of maternal knowledge is inevitably precarious: the less particularized, and the less concretely experiential, a group's (or individual participant's) maternal claim, the more likely it is to evoke privatizing, delegitimizing stereotypes. Yet invoking this role in policy debates directly related to mothering, or to the education or security of children, may be a powerful tool, as the efficacy of Mothers Against Drunk Driving, the Million Mom March, and maternal intervention in the formulation of European social welfare policy have suggested. ${ }^{130}$ Specific maternal experience may be a useful source of knowledge on which to base a particular proposal for political action. ${ }^{131}$

belonging to the private, child-rearing sphere have resulted in male workers obtaining systematic advantages over their female colleagues).

129 See, e.g., Williams, supra note 128, at 813-21 (discussing the employer's litigation strategy in EEOC v. Sears, Roebuck \& Co., 628 F. Supp. 1264 (N.D. Ill. 1986), aff d, 839 F.2d 302 (7th Cir. 1988), and arguing that the decision "enshrine[es] gender stereotypes at the heart of Title VII").

130 See generally Mothers of A NeW WORLD: MATERNALIST POLITICS AND THE ORIGINS OF WELFARE STATES, supra note 8 (discussing the role of "maternalist" political movements in bringing about social change in Europe and the United States during the nineteenth and twentieth centuries). I would note, however, that even in these successful interventions, mothers appear not as paradigmatic political participants, but as ambassadors from another domain whose very appearance in the political realm signifies the importance of the issue to the familial sphere.

${ }^{131}$ A useful distinction here may be between broad assertions of maternal knowledge that may evoke the nineteenth-century ideology of the separate sphere, and narrow experiencebased assertions of maternal knowledge in particular settings that might inform policymaking in those settings. Justice O'Connor evoked this kind of distinction - in reference to sex rather than to maternalism, in particular - in her opinion in J.E.B. v. Alabama, when she argued that women should be included in juries not because of some universal or innate quality that affected their judgment differently from that of men, but because the distinctive features of their life experience gave them a perspective that might inform deliberation in certain kinds of cases. See J.E.B. v. Alabama ex rel. T.B., 511 U.S. 127, 148-49 (1994) ( $\mathrm{O}^{\prime}$ Connor, J., concurring). In basing her maternal claim on her concrete experience of loss - having "skin in the game" - particularly in opposition to a set of political leaders who had no direct experience of war, Cindy Sheehan maintained herself, at least for a time, on the more politically-effective side of this divide. 
The strategy of combining maternalism with other salient, sometimesgendered images may also be either self-defeating or promising. It is not clear, for example, that CODEPINK's articulation of maternalism with "girlie" feminism and direct-action performance has worked successfully in the antiwar context. Its proliferation of images - particularly within such a large, diffuse organization - may have been too much; in a campaign that seeks to confront the public with a potent message, less may be more. But the strategy of rearticulating maternalism, or gender, more broadly, through its combination with ostensibly dissonant elements, may also contribute to women's assertions of citizenship over the long run. Over time the unfamiliar or discordant character of the claim may revise conventional understandings, rather than delegitimize the protest. The examples of women-led antiwar protest movements I have examined here suggest two strategies of protest that may hold particular promise for such revision.

To take one example, articulating motherhood together with an attribute having strong affirmative political valence - such as indignation or anger may, over time, have educative, or even transformative, effects. Cindy Sheehan's maternal anger may at first have been unsettling, but as she continued to air her sense of injury and indignation, members of the public had the opportunity to discover that she was not, in fact, a vengeful harpy intent on devastation. She was, and is, a woman who has suffered a painful loss, and who demands that the government account to her for that loss. Over time, exposure to such political personae may make women's maternal anger more familiar and intelligible.

Similarly, women's projection of a variety of images of gender in connection with citizenship may contribute to an effective long-term strategy. CODEPINK may have offered too wide or too improbably-combined a range of images for its single, time-limited campaign. However, when women articulate their gender together with identities based on race, class, religion, or work - and when they combine these hybrid images with a range of nongendered roles - it may break down stereotypes and help male participants see women, individually and collectively, as plural in their orientations and selfunderstandings.

Finally, Women in Black's style of protest, which draws on women's position as "other" to bear witness to the failings in governmental action, also reflects distinctive liabilities and opportunities. Women's ability to bear witness to injustice draws on their marginality in the political sphere and on their ostensibly superior moral sense - both vestiges of "separate spheres" ideology that women should be hesitant to deploy. ${ }^{132}$ Yet it may be possible for women to frame their "outsider" status more narrowly, and ascribe it not to

132 The fates of women "witnesses" who have deployed their "otherness" to oppose, or even to guide the state - a tradition going back to Antigone and other heroines of classical tragedy - should also inspire caution. See Allison Anna Tait, Family Model and Mystical Body: Women's Witnessing Through Political Metaphor, WOMEN's STUD. Q. (forthcoming 2008) (article on file with author). 
some inherent, gendered condition, but to a gender-based (or more specific group-based) insulation from specific forms of socialization. Women in Black's refusal of the familiar claims of family and religion may, for example, reflect an effort to position their members at some distance from the forces of socialization that contribute to group-based hatreds, militarization, and war. Such explicit positioning may permit women as political actors to serve as a kind of witness, challenging those operating within the frames from whose influence they enjoy greater freedom, to reconsider the inevitability of their position.

Such imagery may help to pluralize the images we hold of citizenship, and of dissent; it may even call into question the naturalness or necessity of male styles of political leadership or dissent - in the way that, as queer theorists have argued, dressing in drag not only enlarges the intelligible range of gender performances, but challenges the naturalness of the male/female binary. ${ }^{133}$ Admittedly, the stakes are high in such efforts, and context is everything. A masterful direct-action strategy or deep political commitment may be necessary to counter and recast the impression created by the pink-slip-toting, sneaker-purchasing dissenter. But images that confront stereotypes instead of stumbling onto the political/legal fault line of the generalized maternal claim may hold more promise in claiming public attention and in reconstructing gendered understandings of citizenship.

\section{CONCLUSION: ANTIWAR PROTEST AND THE PRESENT MOMENT IN WOMEN'S CITIZENSHIP}

If the tensions involved in asserting gender in political protests suggest that the glass of women's citizenship remains half-empty, there are other features of these three efforts that may nonetheless depict the glass as half-full. First, it is significant that women are now claiming leadership of a political movement that entails one of the most difficult roles a citizen can play: offering dissent over the waging of war, where the state faces a threat, and there is a reflexive demand, by the government and many of its citizens, not for contestation but for obedience. This development, like Nancy Pelosi's recent election as Speaker of the House or Hillary Clinton's front-running campaign for the 2008 Democratic nomination for President, suggests a broadening of women's horizons or aspirations as citizens. Women may still be experiencing equivocal results (as indeed men often do), but they are experiencing them in a wider and more ambitious range of political contexts. These protest roles connote the same aspirations to leadership and visible authority; yet the demands of civil disobedience or direct-action protest also entail a physicality

133 See, e.g., Judith Butler, Gender Trouble: Feminism And the Subversion of IDENTITY 136-38 (1st ed. 1990) (arguing that "drag fully subverts the distinction between inner and outer psychic space and effectively mocks both the expressive model of gender and the notion of a true gender identity"). 
and an assumption of physical risk that has not traditionally been thought to inhere in women's citizenship.

Second, in this novel and precarious task of demanding wartime government accountability, women are playing an agentic part in managing the culturallyconstructed contradictions of their role. They are negotiating the balance between the gendered and the gender-neutral in interesting and creative ways. For example, as dissenters, they are wrapping themselves in the explicitly gender-neutral protections of the First Amendment to make a claim that invokes gendered knowledge and involves explicitly gendered performances. ${ }^{134}$ They are also balancing the reductive character and potential political liabilities of the maternal role by rearticulating this traditional claim with other attributes of gender, including unconventional and unfamiliar depictions of women's bodies, emotions, and relation to the political sphere. It is perhaps not surprising that these depictions have prompted a backlash from government officials or members of the public. In their unfamiliarity, and their potential to expand or disrupt conventional assumptions about both gender and citizenship, they may be genuinely unsettling. In the short run, as I observe above, they may be as much a liability as an asset to women objecting to government war-making. But they enlarge the range of representations from which women draw in performing their roles as citizens, and in the long run, they have the potential to expand the narrow conceptual spaces to which women's political participation has been confined, and to revalue nowstigmatized images. ${ }^{135}$

Third, in embracing this challenging role, women are making a claim, not for themselves in particular, but for the entire polity. Their claims as protesters in these movements entail a demand for governmental accountability to the nation as a whole, rather than a demand for inclusion on their own behalf. Demands for accountability are not unfamiliar in protest movements, but they have been far less typical in female-led movements. ${ }^{136}$ Women have

${ }^{134}$ I thank Hila Keren for this insight.

135 Women's performance of roles and acts that men have more conventionally undertaken may initially seem incongruous, but may ultimately undermine some gendered political assumptions by challenging the naturalness or necessity of men's exclusive occupation of particular political roles.

136 There are, of course, exceptions to this general observation. Women have led political movements aimed at achieving greater inclusion for the participants. Examples include women's participation in the temperance and abolitionist movements (however, it is also true that many of these women hoped or imagined that women's suffrage might be achieved at the same time as the enfranchisement of the former slaves). See DuBols, supra note 7 , at 22 (describing female participation in antislavery and other reform movements as the source of the antebellum women's rights movement). Of these two movements, the abolitionist movement may have a stronger claim as a political movement that demanded accountability of the government for a flawed or culpable choice (as well as demanding a new choice). However, the temperance movement might also be seen in this light if contemporary readers or political actors were more inclined to credit its moral claims. 
historically lacked the political authority to call governments to account; their efforts have more frequently been aimed at achieving the formal indicia of citizenship, or securing a place at the policymaking table. In these examples, however, women stake their ground as citizens by demanding not equality for themselves but accountability to the nation as a whole. Cindy Sheehan seeks an explanation of the "cause" for which her son died; she wants, from the government and for the nation, a discussion of what goals could justify the kind of suffering the war has produced, on both sides. Although her manner is noisy and clamorous rather than silent and austere, Sheehan, like the Madres of the Plaza de Mayo, is challenging her government and her fellow citizens to introspection and dialogue regarding the choices and the costs embodied in the war effort. The demand for accountability is also implicit in the strategies of Women in Black and CODEPINK: the austerity, or the outrageousness, of the demand that the government stop its militaristic aggression challenges the state to explain its actions and justify its plans for continuation. This choice seems significant in a number of ways: it suggests that women can see themselves as sufficiently included to make demands of another sort, and can see the universalizing, as well as the "minoritizing," dimensions of their own political efforts. ${ }^{137}$

Finally, even in the politically-vexed present, these women-led antiwar movements have enjoyed some valuable forms of success. They have claimed the attention of a media-saturated public, and even if they haven't succeeded in stopping the war, or wholly transforming the public discourse, some have contributed to a palpable escalation of protest. They have confronted the public with novel images of gendered citizenship, and only in extreme cases have they been told to get back in the kitchen and stop their protests. They have affirmed the ability of women to engage in highly visible confrontation with governmental actors at the highest levels, to initiate innovative strategies of direct-action protest or civil disobedience, and to act, even if temporarily, as the de facto leaders of the nation's antiwar movement. Though they may be contested and their effects may be equivocal, these are no small accomplishments. These protesters reflect and create a larger repertoire of roles for women as they engage in more ambitious political contexts.

137 As Eve Sedgwick explains, the "minoritizing" dimension of a particular representation or problem directs attention to the specific circumstances of a minority or non-conforming group; whereas the "universalizing" dimension evokes the way that attributes or problematics associated with a particular group have resonance in a society or culture more generally. EVE KosofSKY SEDGWICK, EPISTEMOLOGY OF THE CLOSET 1 (1990) (describing the "contradiction between seeing homo/heterosexual definition on the one hand as an issue of active importance primarily for a small, distinct, relatively fixed homosexual minority (what I refer to as a minoritizing view), and seeing it on the other hand as an issue of continuing, determinative importance in the lives of people across the spectrum of sexualities (what I refer to as a universalizing view)"). 